Jpn. J. Oral Biol., $29: 643-651,1987$.

\title{
凍結割断レプリカ法によるラット切歯歯骫血管の観察
}

\author{
田畑正志仙波輝彦和田薫 \\ 鹿児島大学菌学部口腔解剖学教室第 1 (主任: 仙波輝彦教授)
}

〔受付：昭和62年 4 月 10 日〕

\section{The blood vessels in rat incisor pulp by the freeze-fracture method}

\author{
Shoji Tabata, Teruhiko Semba and Kaoru Wada \\ Department of Oral Anatomy, Kagoshima University \\ Dental School, Usuki-cho, Kagoshima 890 Japan \\ (Chief: Prof. Teruhiko Semba)
}

[Accepted for publication: April 10, 1987]

Key words : Blood vessels / rat incisor pulp / TEM / freeze-fracture method

\begin{abstract}
The blood vessels in the rat incisor pulp were studied by transmission electron microscopy (TEM) of freeze-fracture replicas. The fenestrae of fenestrated capillaries were randomly distributed, circular and 50 to $60 \mathrm{~nm}$ in diameter. The coalescence of about 30 to 40 fenestrae constituted a fenestrated area. Nonfenestrated areas were so extensive that fenestrated areas were widely separated. En face views were obtained of junctions between adjacent endothelial cells of continuous capillaries and venulae. The junctions of continuous capillaries were thought to be discontinuous zonula occludens, rather than perfect zonula occludens, because some gaps of about $10 \mathrm{~nm}$ could be seen in them. The junctions of venulae were the tight junctions constituting of 1 to 2 strands and the low profiles of linear creases.
\end{abstract}

\section{緒言}

硬組織に周囲を包まれ，保護されている構造に おいて歯髄は脳に似ている。事実かなり太い静脈 でさえ，その中膜の発達が悪いことなどは類似性

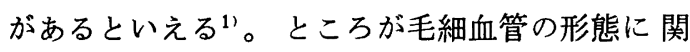
しては，かなり違ってくる。血液脳関門2,3) で示 されるように, 脳では毛細血管はすべて連続型 で，物質の透過性はかなり悪い。これに対し，例 えばラット切歯歯髄では，その微小領域に有空型 と連続型の両型の毛細血管が，それぞれ局在して

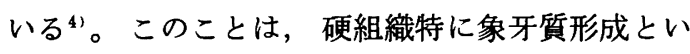

鹿児島市宇宿町1208番地の1（广890）
う歯髄の機能に対して，歯髄中の血管が，物質供 給の面から応えた結果だと考えられる。果たし て，この血管の透過性に関わる構造は，どのよう に形成されているのだろうか。この疑問を明らか にするため，著者らは凍結割断レプリカ法を用い た。

凍結割断法は1950年代後半 Steere により開発 され，その後1966年 Branton により，この方法 での膜の内部が見えることが示された5)。この方 法の利点は広い範囲で膜の, 正確には膜内部の正 面観 (en face views) を得ることができることで ある。例えば超薄切片法を用いて，内皮細胞間の 接合状態を検索するのは，それらの二次元的構造 を詳細によることはできても，三次元的広がりを 
把握することに非常な困難をともなう。そのため 物質の血管内皮通過に関する論争に，なかなか終 止符が打たれないでいるのが現状であり ${ }^{6)}$ ，この ことについては考察で再び述べる。本論文の研究 法として用いた凍結割断法は現在のところ，この 問題に対する最も良い解決法であると考えるの で，得られた結果を報告する。

\section{材料および方法}

20〜30日龄の Wistar 系ラットを $3.0 \%$ グルタ ールアルデヒド $(0.1 \mathrm{M}$ cacodylate buffer, $\mathrm{pH}$ 7.4）で灌流固定し，下頡切歯を取り出した。同 固定液中で 4 時間, 水水温下にて浸漬固定した。 固定終了直前，実体顕微鏡下でピンセットを用い て，エナメル質と象牙質を静かに取り除き，象牙 芽細胞が付着した状態の歯髄を取り出した。この ようにすると，脱灰操作を省けて便利である。cacodylate buffer で数回洗浄後, phosphate buffered saline に30\%の割合に溶かしたグリセリンに 一晚, 水水温下で浸漬した。

凍結は真空ポンプで急速に減圧し，スラッシュ 状を呈した液化窒素中に，試料台ごと試料をすば やく投入して行った。エイコー社製 FD-3 型凍 結割断装置を用いて, 高真空 $\left(3 \times 10^{-7}\right.$ Torr 以 下), 低温 $\left(-130^{\circ} \mathrm{C}\right)$ 下で凍結割断後, 白金で回 転蒸着し，炭素を上方から蒸着してレプリカを得 た。超薄切片の作製法については, 以前に報告し た通りである ${ }^{4)}$ 。観察は日本電子 $200 \mathrm{CX}$ 型もし くは日立 $\mathrm{H} 300$ 型透過電顥を用いて行った。レプ リカを撮影したネガフィルムは図 6 を除き 1 回反 転した後，印画紙に焼き付けた。このため蒸着量 の多い部分は白く，少ない部分は黒く見える。

\section{結果}

本研究には切縁側に近い切歯中部を材料に 用い た。この部位には象牙芽細胞層の中に有空毛細血 管が，またこの細胞層直下には連続型毛細血管が 存在するといったように，二種類の毛細血管が近 接した距離内に存在する。これは凍結割断法のよ うな偶然性の多い技術を用いる場合，目標とする 血管の観察頻度が多くなるという利点をもってい る。以下三種の血管について観察所見を述べる。

\section{有空型毛細血管 (Fig. 1 Fig. 3)}

切歯中部より切縁側にかけて, 象牙芽細胞層の terminal web 直下に毛細血管網が存在する ${ }^{7-10)}$ 。 ここに見られる毛細血管は象牙質が切縁側へ 成長 するに従い，連続型からしだいに有空型へと形態 変化する ${ }^{4}$ 。内皮細胞の空は象牙質側に向って分 布する傾向が特に強く，その径は $50 \sim 60 \mathrm{~nm}$ とほ ぼ均一である。その形は正円に近く, P 面 (P-fracture face) のくぼみ $\mathrm{E}$ 面 (E-fracture face) の突 出として認められる。その中心部には超薄切片 法での隔膜(diaphragma)に見られる結節 (central knob）と同等構造物と思われる肥厚部分が見られ る場合もある。空は形質膜小胞の開口部に比べて その径が大きくまたその底面が浅いので，両者の 区別は容易である。空は30〜40個がひとつの集団 として有空野 (fenestrated area ${ }^{11}$ ) を形成する が，これらの空の配列についてはこの有空野の中 で一定の規則的分布を見出し得なかった。また 有空野相互閒には空を持たない幅広い内皮部分 (nonfenestrated area) が介在し互いに隔てられて いる。なお空状構造のなかには底面が極端に浅く 膜内粒子を認め難いものがある。これらは空に黒 い縁どりが見られることにより，ようやくその存 在が認められ，これらは空の形成過程中にあるも のであろうと考えている。

\section{連続型毛細血管 (Fig. 4 Fig. 6)}

象牙芽細胞層直下あるいはそれより内側の 歯髄 中に見られる毛細血管は連続型である。連続する 内皮細胞中に含まれる形質膜小胞の数はあまり多 くない。凍結割断レプリカ法の利点のひとつは, 内皮細胞相互の接合部分の正面観を広い範囲に 得 ることができることである。ここでは $\mathrm{P}$ 面での隆 起と $\mathrm{E}$ 面での溝から成る内皮細胞間の 密着結合 (tight junction) が認められる（Fig. 6)。ほぼ平 行に走る $2 \sim 3$ 条のストランド (strands) は，と ころどころで分断し結果として幅 $10 \mathrm{~nm}$ 程の不 連続部よりなる間隙を作っている。この結合は内 皮細胞間を完全にシールしているわけではないの で，密着帯（zonula occludens）というよりは不 連続密着帯 (discontinuous zonula occludens) と 呼ぶのが適切であるように思える。

静脈性の血管 (Fig. 7 Fig. 9 ) 
歯髄中には中膜が欠如してあたかもその構造は 毛細血管様ではあるが，その径が大きいことから それとは言い難い静脈性の血管が多数存在してい る。内皮細胞間の接合部分には, $\mathrm{P}$ 面上の隆起と $\mathrm{E}$ 面上の溝として認められる1〜2条のストラン ドが見られる。また静脈性の血管には線条ひだ (linear crease ${ }^{12)}$ ) と呼ばれる構造がP面上では 畧状隆起として， E面上では溝状として存在して いる。線条ひだの存在は静脈性の血管の特徴のひ とつである。Fig. 9 に見られるように，E面上の ストランドの溝の中に多数の膜内粒子が 存在して いる。

\section{考察}

ラット切歯歯髄には連続型と有空型の両型の 毛 細血管が存在している ${ }^{13)}$ 。そ扎らは歯㵦中に混在 しているわけでなく，かなり局在性を示してい る。有空型毛細血管は切歯中部の young odontoblasts $^{14)}$ と呼ばれる象牙芽細胞層中より出現し始 め, 切歯が切縁側に成長するにつれ連続型より有 空型へと形態変化をおこす ${ }^{4}$ 。連続型毛細血管は 象牙芽細胞層直下に一層をなして見られる ${ }^{9,10) 。 ~}$ このように微小領域に 2 種類の毛細血管がそれぞ れ局在している切歯歯髄は，血管の形態と機能の 関連を研究する上でとくに有用な材料である。

凍結割断法を用いた有空型毛細血管の空に関す る報告は，すでに小腸および萃臓を用いて行なわ れている ${ }^{15)}$ 。切歯歯髄中の有空型毛細血管の空 は, その形および径において, 小腸のものと大差 ないと思われる。ところがその分布状態に著しい 違いが認められる。

小腸の有空型毛細血管は空が非常に密集して有 空野を形成し，しかも空のない内皮部分である細 胞質稜 (cytoplasmic crests) が狭い，という特徵 を持つのに対し，歯髄のものは有空野における空 の密集性は低く，空のない内皮部分は非常に広 い。このことは歯䯑有有空型毛細血管の体液透過量 が，小腸のものに比べて明らかに少ないことを物 語っていると考えられる。

次に, 連続型毛細血管の隣接する内皮細胞間の 接着装置のことについて述べる。分子量およそ 4 万, 径約 $3 \mathrm{~nm}$ の西洋ワサビペルオキシダーゼ
(HRP) を用いた Karnovsky ${ }^{16)}$ のトレーサー実 験によると, 連続型毛細血管の場合, 内皮細胞間 をHRP が通過できることから，彼はそこに幅 $4 \mathrm{~nm}$ 程度の間隙があると考えた。内皮細胞間の 結合は密着帯（zonula occludens）ではなく密着 斑（macula occludens）であると論じた。一方， Palade らのグループによると，血管内皮の細胞間 接合部のほとんどは形態的にタイト（tight）な状 態であり，機能的に $11 \mathrm{~nm}$ の大きさのフェリチン から $3 \mathrm{~nm}$ のミオグロビンあるいは $2 \mathrm{~nm} の$ hemepeptideに対して透過性を示さなかった ${ }^{17-20 !}$ 。 このように物質の毛細血管内皮通過の問題に関し

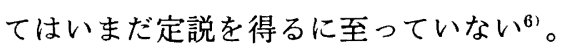

凍結割断法の利点は膜, 正しくは膜内部の広い 正面観を得られることである。この方法を用いる と, 広い範囲に隣接する内皮細胞間の接合部分を 観察できる。歯髄の連続型毛細血管の場合, 幅 10 $\mathrm{nm}$ 程度の間隙が接着装置のストランド中に点在 していた。実際にはこの方法で, 内皮細胞間の接 合面における細胞膜の真の表面での微細構造に関 して，直接情報を得ることはできないが，著者ら は、ここに述べた間隙の存在がこの部位で小物質 が出入りしていることを，形態的に反映している ものだと考えている。

Simionescu ら ${ }^{12)}$ は, 凍結割断レプリカ法を用 いて筋組織中の血管を観察している。それによる とタイト結合のストランドに関して, 細動脈と毛 細血管は $\mathrm{E}$ 面上の溝に多数の膜内粒子を入れてい る。歯髄の場合，静脈性の血管においても同様 に, $\mathrm{E}$ 面上の溝に膜内粒子を多数残すという結果 を得た。このようなことは，他の上皮のタイト結 合ではめったに見られないことである（そのよう なまれな例は文献21)を参照)。絶えず流れ続ける 血液に対して, 細胞膜外葉を安定化させるための 内皮の適応性を示すものだと理解される。

終生成長を続けるラット切歯の歯髄に存在する 毛細血管は，連続型から有空型へと形態変化す る4”。なかんずく，その中部は変化中のものが多 く見られるため, 空の形成過程を研究するのに好 都合の材料であり，部位でもある。著者らは，こ の部位の内皮細胞に，底面のかなり浅い円形の輪 郭をもった構造を認めた。その形状とか径が通常 
の空棈造と一致すること，さらにこの部位で空形 成が盛んに進行していることなどから，我々は， それらが空形成過程の一段階を示す構造ではない かと考えている。Lombardi ら ${ }^{221}$ は，単離クロー ン化した牛副腎皮質内皮細胞を用いて， phorbol myristate acetate によりその空の形成を増加方向 一刺激を行った。その結果, 同様の円形輪郭をも った浅い凹み構造が出現すると報告し，彼らもこ の構造が 空形成過程の一段階を示すものだと考察 している。

\section{結論}

凍結割断レプリカ法を用いてラット切歯歯髄中 の血管を観察し，次のような結論が得られた。
（1）有空型毛細血管の空は円形で，その径は50 $\sim 60 \mathrm{~nm}$ である。空は30〜40個がひとつの集団と して有空野を形成する。有空野相互間には幅広い 無空野が介在し互いに隔てられている。

（2）連続型毛細血管の隣接する 内皮細胞間の夕 イト結合は，2３条のストランドから成る不連 続性密着結合である。

（3）静脈性の血管の接着装置は，1２条のス トランドから成るタイト結合と線条ひだにより 形 成されている。

この研究の一部は, 昭和61年度文部省科学研究費補助 金, 奖励研究 (A)（課題番号61771409） と，総合研究 (A)「菌噵の防御反応機構の分子生物学的研究」(課題 番号61304035，代表者，辻本明）により行われた。

抄録：凍結割断レプリカ法を用いてラット切歯歯髄中に存在する血管を観察した。有空型毛細血管の空は 円形でその径は 50 60 nm と均一である。空は30 40個がひとつの集団として有空野を形成する。有空野 相互間には幅広い無空野が介在し互いに隔てられている。連続型毛細血管の内皮細胞間の接着装置は, とこ ろどころに $10 \mathrm{~nm}$ 程の間隙をもつ $2 \sim 3$ 条のストランドから成る不連続性密着結合である。静脈性の血管 の内皮間接着装置は $1 \sim 2$ 条のストランドから成るタイト結合と線条ひだにより形成されている。

\section{文献}

1）藤田尚男, 藤田恒夫 : 標準組織学, 第 2 版, 各 論, pp. 1-35, 医学書院, 東京, 1984.

2) Dobbing, J. : The blood-brain barrier. Physiol. Rev. 41 : 130-188, 1961.

3) Reese, T. S. and Karnovsky, M. J. : Fine structural localization of a blood-brain barrier to exogeneous peroxidase. J. Cell Biol. $34:$ 207-217, 1967.

4）田畑正志，仙波輝彦：ラット切歯歯髄毛細血管 の部位的変化, 歯基礎誌 27 : 1055-1064, 1985.

5) Alberts, B., Bray, D., Lewis, J., Raff, M., Roberts, K. and Watson, J. D. (中村桂子, 松原謙一監訳）：細胞の分子生物学, 上巻 pp. 148-159, 教育社, 東京, 1985 .

6) 山元寅男: 毛細血管の微細構造と透過性, 細胞, 12巻 1 号, pp. 6-11, ニューサイエンス社, 東京, 1985 .

7) James, W. W.: The blood capillary system of the odontoblast layer of the dental pulp. J. Anat. 89 : 547-549, 1955.

8) Adams, D.: Paripheral capillaries in the rodent incisor pulp. J. Dent. Res. 38 : 969978, 1959.

9）仙波輝彦：象牙質の体液流動に関する形態学的 考察, 鹿歯紀, 第 2 巻, pp. 1-9, 1982.
10）仙波輝彦, 田畑正志, 山本博崇：合成樹脂鋳型 法によるラット下䫟切歯血管の立体構筑につい て, 鹿大医誌 35 : 141-152, 1983.

11) Fawcett, D. W. : Bloom and Fawcett, A Textbook of Histology. 11th ed. pp. 367405, Igakushoin/Saunders International Edition, Tokyo, 1986.

12) Simionescu, M., Simionescu, N. and Palade, G. E. : Segmental differentiations of cell junctions in the vascular endothelium. The microvasculature. J. Cell Biol. 67 : 863-885, 1975.

13) Semba, T. and Ishida, M.: On the fluid flow in the pulp of young rat incisor. Proc. 10th Int. Cong. Anat., Yamada, E., ed., Science Council of Japan, 409, 1975.

14) Takuma, S. and Nagai, N.: Ultrastructure of rat odontoblasts in various stages of their development and maturation. Arch. Oral Biol. 16 : 993-1011, 1971.

15) Simionescu, M., Simionescu, N. and Palade, G. E. : Morphometric data on the endothelium of blood capillaries. J. Cell Biol. 60 : 128-152, 1974.

16) Karnovsky, M. J. : The ultrastructural basis of capillary permeability studied with peroxidase as a tracer. J. Cell Biol. 35 : 213-236, 1967. 
17) Simionescu, N.: Cellular aspects of transcapillary exchange. Phisiol. Rev. $63: 1536$ 1579, 1983.

18) Bruns, R. R. and Palade, G. E. : Studies on blood capillaries. II : Transport of ferritin molecules across the wall of muscle capillaries. J. Cell Biol. 37 : 277-299, 1968.

19） Simionescu， N.：毛細血管透過性の構造的基 盤. 生体の科学 $27: 152-161,1976$.

20) Palade, G. E., Simionescu, M. and Simionescu, N.: Strucural aspects of the permeability of the microvascular endothe- lium. Acta Physiol. Scand. Suppl. 463 : 1132, 1979.

21) Claude, P. and Goodenough, D. A.: Fracture faces of zonulae occludentes from " tight and leaky" epithelia. J. Cell Biol. 58 : 390-409, 1973.

22) Lombardi, T., Montesano, R., Furie, M. B., Silverstein, S. C. and Orci, L. : Endothelial diaphragmed fenestrae : in vitro mod. ulation by phorbol myristate acetate. J. Cell Biol. 102 : 1965-1970, 1986. 


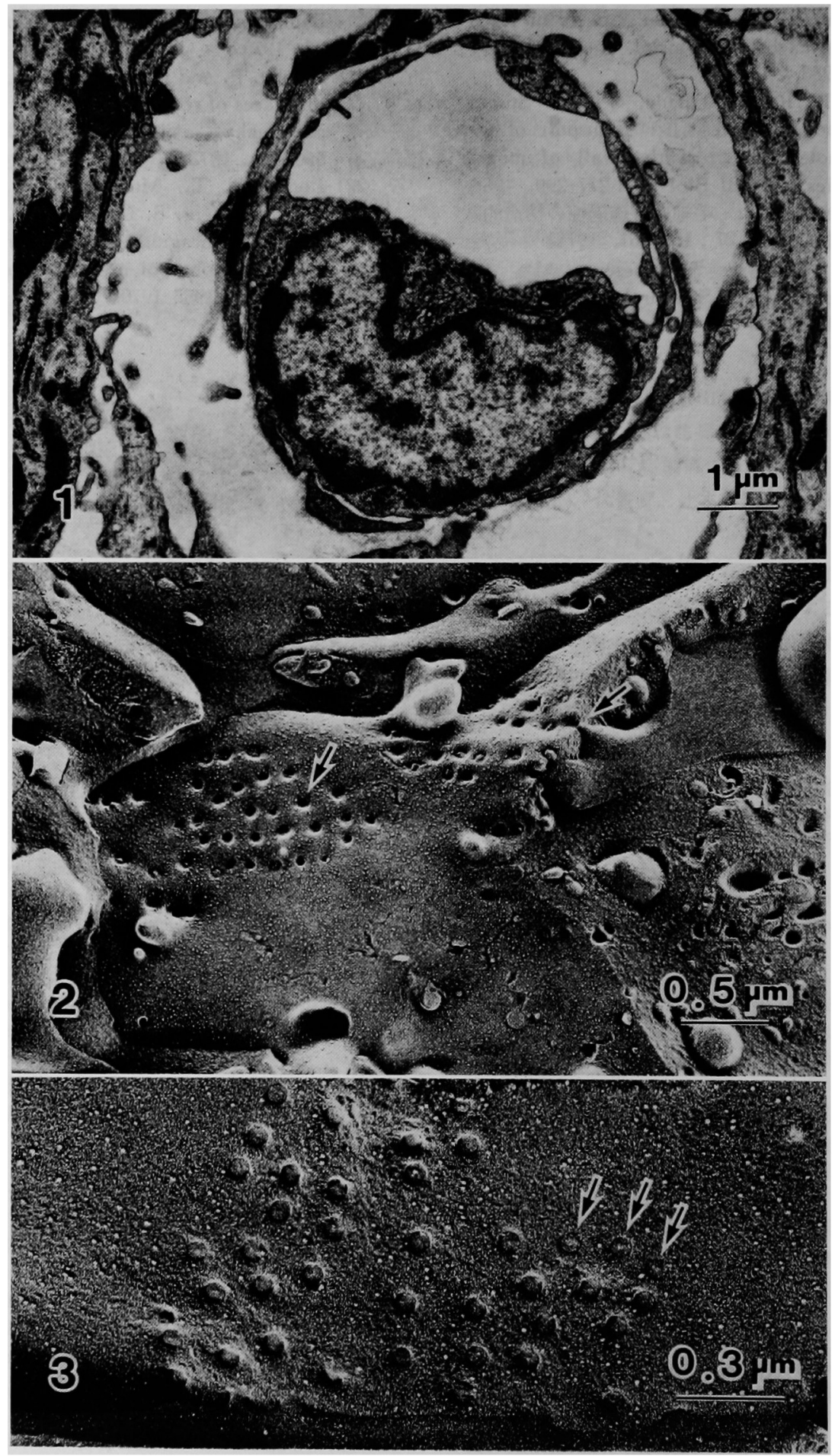




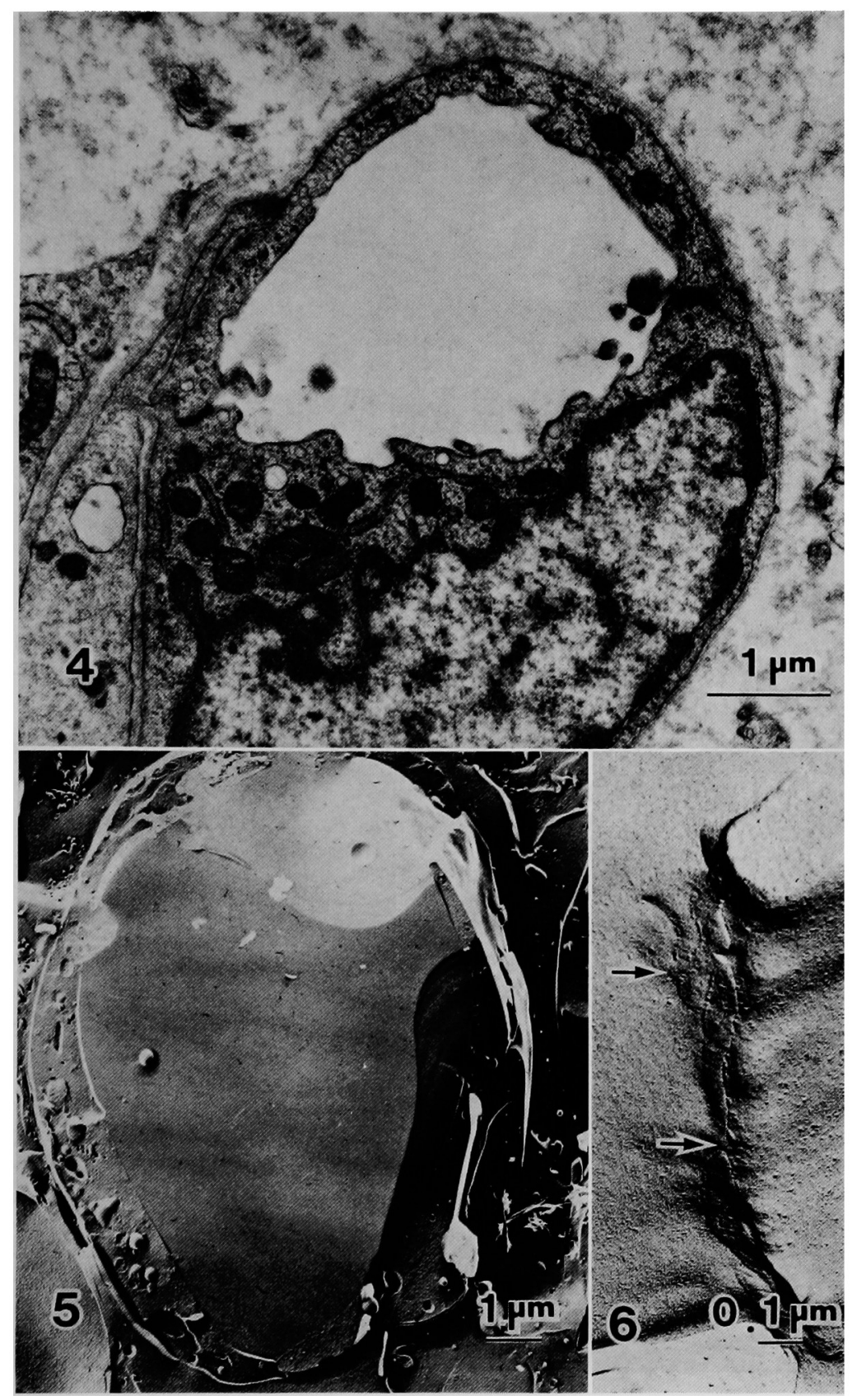




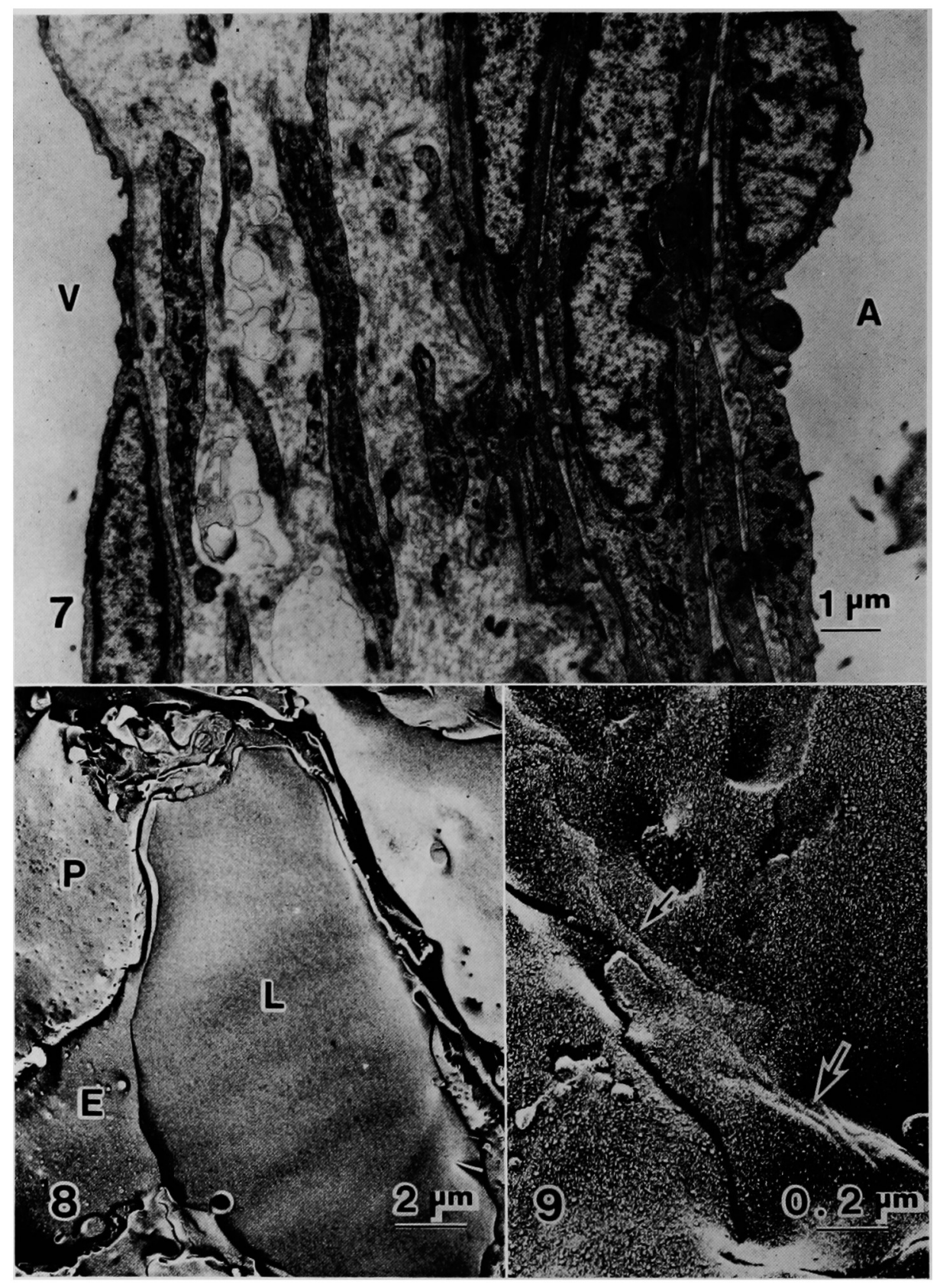




\section{EXPLANATION OF FIGURES}

Fig. 1 A fenestrated capillary in the odontoblastic layer. $(10,000 \times)$

Fig. 2 Freeze-fracture replica of a fenestrated capillary in the odontoblastic layer. The fenestrations are seen as circular grooves on the P-fracture face or circular protrusions on the E-fracture face (arrows). $(24,000 \times)$

Fig. 3 The P-fracture face of a fenestrated capillary in the rat incisor pulp. Very shallow hollows of fenestrae (arrows) are seen around the normal fenestrae. These structures are thought to represent intermediate stages in the process of pore formation. $(48,000 \times)$

Fig. 4 A continuous capillary in the pulp. $(15,000 \times)$

Fig. 5 Freeze-fracture replica of a continuous capillary in the subodontoblastic region. $(7,000 \times)$

Fig. 6 Higher magnification of Fig. 5. A tight junction between two endothelial cells of a continuous capillary. This junction is formed by 2 to 3 parallel strands, and has two gaps of about 10 $\mathrm{nm}$ in it (arrows). (60,000 $\times$ )

Fig. 7 A vein (V) and a artery (A) in the central pulp. $(8,000 \times)$

Fig. 8 Freeze-fracture replica of a venula in the pulp.

P : P-fracture face, E: E-fracture face, $L$ : venular lumen $(5,000 \times)$

Fig. 9 Higher magnification of E-fracture face in Fig. 8. The junction is the tight junction constituting of 1 to 2 strands (small arrow) and the low profiles of linear crease (large arrow). $(50,000 \times)$ 